\title{
Chlorophyll Fluorescence in Guanandi Tree (Calophyllum brasiliense) AFTER HERBICIDE APPLICATION ${ }^{1}$
}

\author{
Fluorescência da Clorofila em Guanandi (Calophyllum brasiliense) Após Aplicação de \\ Herbicidas
}

\author{
ARALDI, R. ${ }^{2}$, CORNIANI, N. ${ }^{3}$, TROPALDI, L. ${ }^{4}$, GIROTTO, M. ${ }^{4}$, BELAPART, D. ${ }^{4}$, SIMÕES, P.S..${ }^{4}$, and \\ VELINI, E.D. ${ }^{4}$
}

\begin{abstract}
Chlorophyll fluorescence is currently used as a rapid diagnostic and nondestructive method to detect and quantify damage on the photosynthetic apparatus of leaves on weeds, crops and ornamental/coniferous trees in response to both environmental stress and herbicides. This study aimed to evaluate chlorophyll fluorescence in guanandi plants (Calophyllum brasiliense) after application of different postemergence herbicides. The experiment was performed in a completely randomized design, with six treatments (control, bentazon, sulfentrazone, isoxaflutole, atrazine and glyphosate) and five replications. The herbicide treatments were applied with a stationary sprayer, and electron transport rate (ETR) was subsequently analyzed with OS5p Multi-Mode Chlorophyll Fluorometer. In the monitored period, guanandi plants subjected to atrazine showed higher sensitivity to chlorophyll fluorescence than the other treatments. Although bentazon is a photosystem II inhibitor, it showed no major changes in electron transport for the studied species and in the monitored period. In summary, ETR is a good parameter to evaluate the effect of some herbicides on Calophyllum brasiliense plants.
\end{abstract}

Keywords: electron transport rate, bentazon, sulfentrazone, isoxaflutole, atrazine, glyphosate.

RESUMO - A fluorescência da clorofila tem sido utilizada como um método diagnóstico rápido e não destrutivo para detectar e quantificar danos no aparato fotossintético das folhas em plantas daninhas, culturas e árvores ornamentais/coniferas em resposta ao estresse ambiental, assim como em resposta aos herbicidas. O objetivo do presente trabalho foi avaliar a fluorescência de clorofila em guanandi (Calophyllum brasiliense) após aplicação de diferentes herbicidas em pós-emergência. $O$ experimento foi realizado em delineamento inteiramente casualizado, com seis tratamentos (controle, bentazon, sulfentrazone, isoxaflutole, atrazine e glyphosate) e cinco repetições. Os tratamentos herbicidas foram aplicados em pulverizador estacionário, para posterior análise da taxa de transporte de elétrons (ETR) com o aparelho Multi-Mode Chlorophyll Fluorometer OS5p. No periodo monitorado, as plantas de guanandi apresentaram maior sensibilidade ao atrazine que aos demais tratamentos, em relação à fluorescência da clorofila. O bentazon, inibidor do fotossistema II, não ocasionou maiores alterações no transporte de elétrons na espécie e nos periodos avaliados. Em sintese, a ETR mostrouse um bom parâmetro para avaliar o efeito de herbicidas na espécie arbórea estudada.

Palavras-chave: taxa de transporte de elétrons, bentazon, sulfentrazone, isoxaflutole, atrazine, glyphosate.

\section{INTRODUCTION}

Guanandi (Calophyllum brasiliense) is a Brazilian tree of the family Calophyllaceae. This species easily adapts to types of soil that are challenging to other species, for example, poor, rocky, or shallow soils, or soils prone to flooding. Guanandi trees are potentially used in reforestation, and sustainable use of their wood is an excellent alternative to predatory use of native trees of endangered species (Lorenzi, 1992).

1 Recebido para publicação em 19.9.2014 e aprovado em 14.10.2014.

2 Laboratório Nacional de Ciência e Tecnologia do Bioetanol, Campinas-SP, Brasil, < rosilainearaldi@hotmail.com>; ${ }^{3}$ Escola Superior de Agronomia “Luiz de Queiroz” Piracicaba-SP, Brasil; ${ }^{4}$ UNESP - Faculdade de Ciências Agronômicas, Botucatu-SP, Brasil. 
The implementation and maintenance of forest restoration projects are usually expensive (Melo, 2005), and a significant part of that cost is related to weed control (Gonçalves et al., 2003). Glyphosate is currently the main herbicide used in reforestation with native species (Cornish \& Burgin, 2005). Given the lack of selectivity of this herbicide, it is applied with direct sprays, which reduces yield and makes it difficult to control weeds in the rows. In addition, there are risks of herbicide drift (Yamashita et al., 2006).

In order to improve weed control methods in reforestation, herbicides with selective action for some agricultural crops have been used empirically. However, there are few studies on potential losses to the development of native species caused by the application of these products (Rokich \& Dixon, 2007). Moreover, when these herbicides are applied at post-emergence, they may cause stress in the crop, for example, by inhibiting photosynthesis, affecting stomatal activity and/or interfering with metabolic and physiological functions of plants (Xiaowen et al., 2010; Varshney et al., 2012). These effects can be either temporary or permanent.

Plant photosynthesis is evaluated by measuring chlorophyll fluorescence, a rapid and nondestructive diagnostic method that detects and quantifies damage to the photosynthetic apparatus in response to environmental stress (Percival, 2004). The technique detects changes in chlorophyll fluorescence due to changes in the activity of photosystem II (PSII), either directly or indirectly caused by herbicides.

Chlorophyll fluorescence analysis is widely used for understanding the mechanisms of photosynthesis itself and also for assessing photosynthetic capacity that is changed with herbicide application (Ireland et al., 1986). This type of evaluation is based on fluorometers and applications, ranging from the rapid identification of injuries caused to the photosynthetic apparatus, even when the symptom is still not visible, to the detailed analysis of the change in the photosynthetic capacity of the plant. Furthermore, this technique allows the observation of the effect of various herbicides on the photosynthetic performance of plants (Darwish et al., 2013), in particular, and the assessment of modes of action as well as crop sensitivity (Menegat et al., 2012).

Thus, the objective of this study was to evaluate chlorophyll fluorescence of leaves of the tree species guanandi (C. brasiliense) after postemergence application of herbicides bentazon, sulfentrazone, isoxaflutole, atrazine and glyphosate.

\section{MATERIALS AND METHODS}

The experiment was conducted and the Advanced Research Center in Weed Science (NuPAM), Department of Plant Production, School of Agricultural Sciences/UNESP, Botucatu, state of São Paulo.

The experimental plots consisted of a seedling of $C$. brasiliense in an early development stage $(30 \mathrm{~cm})$, grown in commercial substrate. Cropping practices performed during the experiment were the same used for the commercial production of seedlings.

The experimental design was completely randomized, with six treatments (five herbicides and a control) and five replications. The treatments consisted of the following herbicides: bentazon (720 g a.i. ha $\left.{ }^{-1}\right)$, sulfentrazone (500 g a.i. ha ${ }^{-1}$ ), isoxaflutole (150 g a.i. ha-1), atrazine $\left(2,500 \mathrm{~g}\right.$ a.i. ha $\left.{ }^{-1}\right)$ and glyphosate $(1,080 \mathrm{~g}$ a.i. ha-1 $)$. These herbicides effectively controlled the main weeds present in areas subject to ecological restoration (Lorenzi, 2000).

The herbicides were applied with a stationary air compressor, fitted with a XR 11002 four-tip spray bar, with tips spaced $0.5 \mathrm{~m}$ apart. Spraying was carried out under constant pressure of 1.5 bar and spray volume of $200 \mathrm{~L} \mathrm{ha}^{-1}$. Temperature during application was $25{ }^{\circ} \mathrm{C}$ and relative humidity was $70 \%$.

After spraying the treatments, the experimental units were transported to a greenhouse (temperature of $28^{\circ} \mathrm{C}$ and relative humidity of $70 \%$ ), where they remained until the end of the assay. Electron transport rate (ETR) was assessed every 24 hours for six days after application (DAA) with an 
OS5p - Opti-Sciences Multi-Mode Chlorophyll fluorometer.

Chlorophyll fluorescence of leaves of C. brasiliense seedlings was determined by measuring ETR, expressed in $\mu$ Mols electrons $\mathrm{m}^{-2} \mathrm{~s}^{-1}=(\mathrm{Y}) .(\mathrm{PAR}) \cdot(0.84) \cdot(0.5)$, equivalent to: (PSII quantum yield) $x$ (measures of photosynthetically active radiation measured in $\mu$ Mols electrons $\mathrm{m}^{-2} \mathrm{~s}^{-1}$ ) $\mathrm{x}$ (leaf absorption coefficient) $x$ (fraction of light absorbed by the antenna complex of PSII). ETR is a measure of charge separation at PSII reaction centers. Default values are used in the equation, but coefficients for both absorption and fraction of light absorbed by PSII can be changed (Laisk \& Loreto, 1996).

As ETR determines the photosynthetic electron transport rate at PSII, the use of ETR value allows to detect the effect of herbicidal action at a concentration of $0.5 \mu \mathrm{mol} \mathrm{dm}^{-3}$. By contrast, the traditional method, which includes measurement of the $\mathrm{Fv} / \mathrm{Fm}$ parameter, detection only takes place at concentrations that are 100 times greater (Korres et al. 2003; Abbaspor et al., 2006). This justifies the use of the methodology described in this paper.

ETR data were expressed as percentages of the control and subjected to analysis of variance by the F-test at 5\% probability. Statistical analysis was performed using the t-test at $10 \%$ probability. MSD values were represented in graphs.

\section{RESULTS AND DISCUSSION}

Chlorophyll fluorescence analysis is based on the fact that the light energy absorbed by chlorophyll is used to drive photosynthesis, and this excess energy is released as heat and fluorescence. Although chlorophyll fluorescence represents about $1-2 \%$ of the absorbed light, that amount is easily detected by fluorometers and is effective to assess physiological processes (BolharNordenkampf et al., 1989; Maxwell \& Johnson, 2000) when plants are subjected to herbicides.

Thus, this analysis yields important information for herbicides that directly interfere in electron transport (PSI and PSII inhibitors) (Dayan \& Zaccaro 2012) and also for light-dependent herbicides, e.g. inhibitors of glutamine synthetase, protoporphyrinogen oxidase and carotenoid biosynthesis (Hess, 2000), as these herbicides cause peroxidation of the lipid bilayer membrane and affect the stability of the photosynthetic apparatus, thus indirectly interfering in thechlorophyll fluorescence.

In this study, a $25 \%$ reduction of ETR was observed 24 hours after spraying bentazon, with subsequent recovery (Figure $1 \mathrm{~A}$ ). Bentazon inhibits electron flow at PSII, but it differs from the typical herbicides of that class (Böger et al., 1977). Macedo et al. (2008) reported that bentazon reduced electron transport chain by $80 \%$ three hours after incubation, but this reduction stabilized at $50 \%$ after 15 hours. This behavior confirms the results of the present study, i.e., guanandi plants had mild initial intoxication, but recovered later. This partial recovery of the photosynthetic inhibition caused by bentazon indicates that, unlike other PSII inhibitors, this herbicide does not cause substantial changes in thylakoids (Macedo et al., 2008).

The response of plant fluorescence after application of sulfentrazone was not significant (Figure 1B), i.e., there was no indirect damage to the photosynthetic apparatus as a result of significant changes in ETR in the study period. During the monitored period, ETR varied around $10 \%$. These small variations can be attributed to environmental conditions, since the photosynthetic capacity of plants can be changed by biotic or abiotic stress, such as temperature, radiation, water stress, salinity, presence of insects or fungi, etc. (Bown et al., 2002).

As for the herbicide isoxaflutole, there was a reduction of $25 \%$ of ETR 48 hours after spraying (Figure 1C) with subsequent recovery. This herbicide inhibits the activity of the enzyme $p$-hydroxyphenylpyruvate dioxygenase (HPPD), which, among other reactions, catalyzes the formation of homogentisic acid, a precursor of plastoquinone. Fluorescence yield on leaves under light and dark conditions showed that the herbicide clomazone also affects chlorophyll fluorescence 24 hours after its application (Ali \& Honwemeier, 2013).

Planta Daninha, Viçosa-MG, v. 33, n. 1, p. 77-82, 2015 

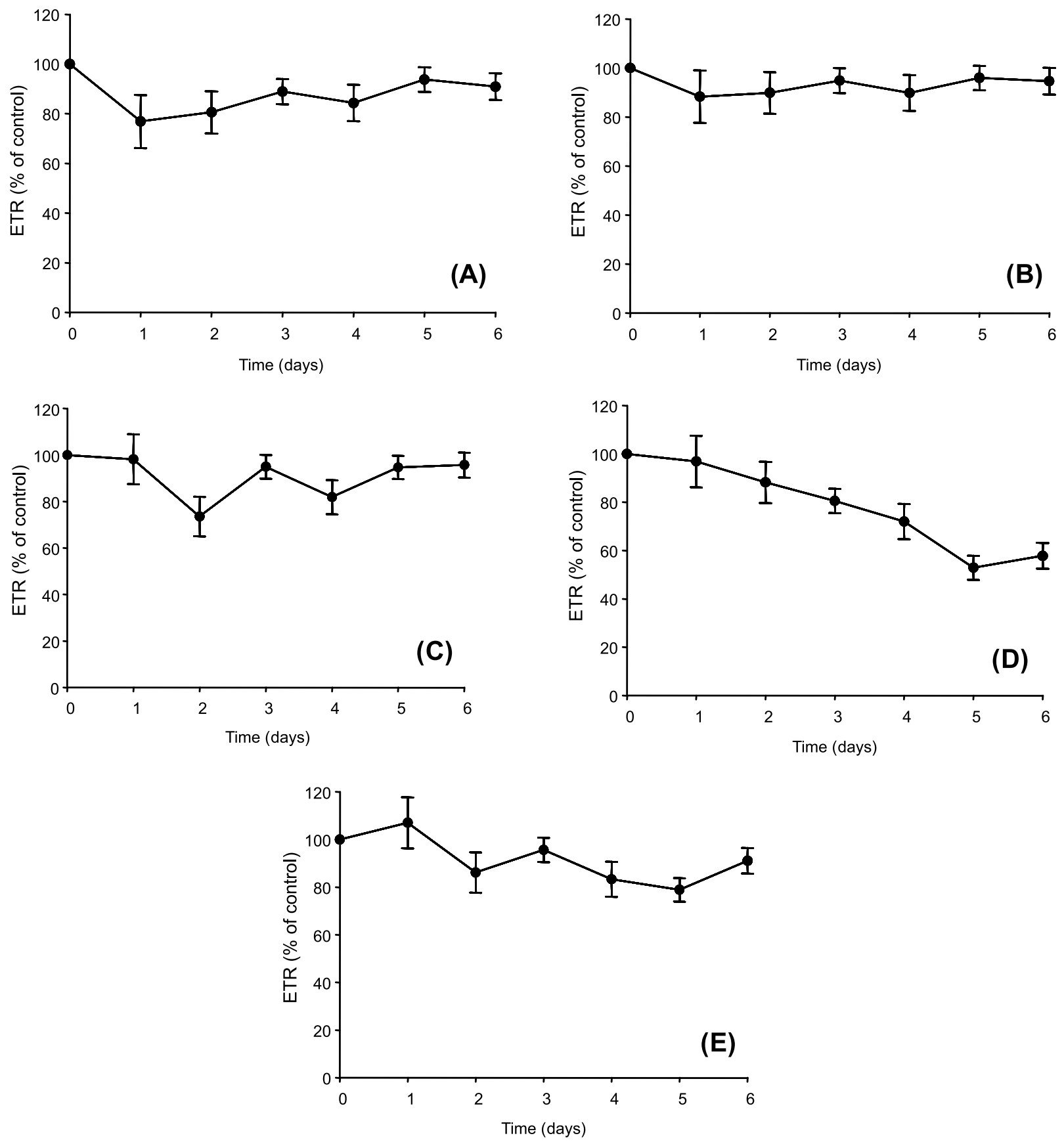

Figure 1 - Relationship between electron transport rate (expressed as a percentage of control) and time (days) in guanandi (C. brasiliense) plants after application of bentazon (A), sulfentrazone (B), isoxaflutole (C), atrazine (D) and glyphosate (E). The bars indicate the MSD in the assessment periods. Botucatu/SP-2014.

ETR in plants treated with atrazine decreased by $50 \%$ five days after spraying (Figure 1D). The herbicide atrazine is recommended for the control of annual eudicotyledons and annual and perennial grasses. In the thylakoids of plant chloroplasts, plastoquinone molecules found in PSII are involved in electron transfer between PSI and PSII (Guisse et al., 1995). This herbicide displaces $Q_{B}$ from its binding site, effectively blocking the electron transport chain between $Q_{A}$ and $Q_{B}$ and causing an increase 
in fluorescence, which was detected by further reducing ETR for guanandi plants during the study period. Dayan et al. (2009), working with atrazine, found intoxication by ETR in corn and weeds. ETR was reduced by $20 \%$ for corn plants 24 hours after application, and there was inhibition of electron transport for weeds. Percival (2005) found that the application of atrazine caused photosynthetic damage to oak leaves (Quercus) three weeks after application, with subsequent recovery of the photosynthetic system after five weeks.

The response of plant chlorophyll fluorescence after application of glyphosate can be observed in Figure 1E. In plants treated with glyphosate, ETR was reduced by $20 \%$ at five DAA. This minimal change in ETR value was possibly due to the mechanism of action of this herbicide, which inhibits the synthesis of aromatic amino acids, causing the gradual death of plants by the structural and functional loss of macromolecules. Dayan \& Zaccaro (2012) also did not find significant changes in chlorophyll fluorescence after applying glyphosate at the concentration of $100 \mu \mathrm{M} 24$ hours after application, and Huang et al. (2012) identified stress in soybean plants through chlorophyll fluorescence only 48 hours after application.

These data are consistent with the response found for Sinapis alba treated with bentazon and glyphosate (Christensen et al., 2003). Other commonly used herbicides, e.g., glyphosate, chlorotoluron, paraquat, diquat, 2,4-D, mecoprop-P and dichlorprop showed no changes caused by herbicides in connection with $Q_{B}$ (Percival, 2005). This indicates that changes in ETR can be used to identify damage to trees caused by drift and inappropriate and/ or appropriate spraying with PSII inhibitors such as atrazine.

Although the physiological principle of fluorescence is complex, the operation of the fluorometer used in this experiment is simple. The chlorophyll fluorescence method is non-destructive and very sensitive, fast and easy to handle. In addition, it shows important information about the photosynthetic apparatus, allowing researchers to quickly describe the performance of the herbicide before visual symptoms appear in plants (Hammami et al., 2014).

For efficient management of herbicide application, early detection of possible damage to the crop is important. Thus, ETR is a good parameter for assessing the effect of some herbicides shortly after spraying.

In the monitored period, guanandi plants treated with atrazine showed higher sensitivity to chlorophyll fluorescence than the other treatments. Although bentazon is a photosystem II inhibitor, it showed no major changes in electron transport.

\section{LITERATURE CITED}

ALI, S.; HONERMEIER, B. Can herbicide stress in artichoke (Cynara cardunculus) be detected by chlorophyll fluorescence? Intern. J. Agric. Biol., v. 15, n. 6, p. 1295-1300, 2013.

BOLHAR-NORDENKAMPF, H. R. et al. Chlorophyll fluorescence as a probe of the photosynthetic competence of leaves in the field: a review of current instrumentation, Funct. Ecol., v. 3, n. 4, p. 497-514, 1989.

BÖGER, P.; BEESE, B.; MILLER, R. Long-term effects of herbicides on the photosynthetic apparatus. II. Investigation on bentazone inhibition. Weed Res., v. 17, n. 1, p. 61-67, 1977.

BOWN, A. W.; HALL, D. E.; MACGREGOR, K. B. Insect footsteps on leaves stimulate the accumulation of 4-aminobutyrate and can be visualized through increased chlorophyll fluorescence and superoxide production. Plant Physiol., v. 129, n. 4, p. 1430-1434, 2002.

CORNISH, P. S.; BURGIN, S. Residual effects of glyphosate herbicide in ecological restoration. Restor. Ecol., v. 13, n. 4, p. 695-702, 2005.

CHRISTENSEN, M. G.; TEICHER, H. B.; STREIBIG, J. C. Linking fluorescence induction curve and biomass in herbicide screening. Pestic. Manag. Sci., v. 59, n. 12, p. 1303-1310, 2003.

DARWISH, M.; LOPEZ-LAURI, F.; SALLANON, H. Study of photosynthesis process in the presence of low concentrations of clomazone herbicide in tobacco (Nicotiana tabacum). J. Stress Physiol. Biochem., v. 9, n. 1, p. 229-245, 2013.

DAYAN, E. D.; ZACCARO, M. L. M. Chlorophyll fluorescence as a marker for herbicide mechanisms of action. Pestic. Biochem. Physiol., v. 102, n. 2, p. 189-197, 2012.

Planta Daninha, Viçosa-MG, v. 33, n. 1, p. 77-82, 2015 
DAYAN, F. E.; TRINDADE, M. L. B.; VELINI, E. D. Amicarbazone, a new photosystem II inhibitor. Weed Sci., v. 57, n. 6, p. 579-583, 2009.

GENTY, B.; BRINTAIS, J. M.; BAKER, N. R. The relationship between the quantum yield of photosynthetic electron-transport and quenching of chlorophyll fluorescence.

Biochim. Biophys. Acta, v. 990, n. 1, p. 87-92, 1989.

GONÇALVES, J. L. M.; NOGUEIRA JÚNIOR, L. R.; DUCATTI, F. Recuperação de solos degradados. In: KAGEYAMA, P. Y. et al. (Ed.). Restauração ecológica de ecossistemas naturais. Botucatu: Fundação de Estudos e Pesquisas Agrícolas e Florestais, 2003. p. 111-163.

GUISSE, B.; SRIVASTAVA, A.; STRASSER, R. J. The polyphasic rise of the chlorophyll a fluorescence (OKJIP) in heat stressed leaves. Arch. Sci. Geneve, v. 48, p. 147-160, 1995.

HAMMAMI, H. et al. Behavior of sethoxydim alone or in combination with turnip oils on chlorophyll fluorescence parameter. Not. Sci. Biol., v. 6, n. 1, p. 112-118, 2014.

HESS, F. D. Light-dependent herbicides: an overview. Weed Sci., v. 48, n. 2, p. 160-170, 2000.

HUANG, Y. et al.. Early detection of soybean plant injury from glyphosate by measuring chlorophyll reflectance and fluorescence. J. Agric. Sci., v. 4, n. 5, p. 117-124, 2012.

IRELAND, C. R.; PERCIVAL, M. P.; BAKER, N. R. Modification of the induction of photosynthesis in wheat by glyphosate, an inhibitor of amino acid metabolism. J. Exper. Bot., v. 37, n. 176, p. 299-308, 1986.

LORENZI, H. Árvores brasileiras - manual de identificação e cultivo de plantas nativas do Brasil. Nova Odessa, SP: Plantarum, 1992. $352 \mathrm{p}$.

LORENZI, H. Manual de identificação e de controle de plantas daninhas: plantio direto e convencional. 5.ed. Nova Odessa: Plantarum, 2000. 339 p.
MACEDO, R. S. et al. Effects of the herbicide bentazon on growth and photosystem II maximum quantum yield of the marine diatom Skeletonema costatum. Toxicol. In Vitro, v. 22, n. 3, p. 716-722, 2008.

MAXWELL, K.; JOHNSON, G. N. Chlorophyll fluorescence- a practical guide. J. Exper. Bot., v. 51, n. 345, p. 659-668, 2000.

MELO, A. C. G. A legislação como suporte a programas de recuperação florestal no Estado de São Paulo. Florestar Estatístico, v. 8, p. 9-15, 2005.

MENEGAT, A. et al. Chlorophyll fluorescence microscreening as a rapid detection method for herbicide resistance in grass weeds in North China plain winter wheat production systems and beyond. Pak. J. Weed Sci. Res., v.18, p. 409-418, 2012. (Special Issue)

PERCIVAL, G. C. The use of chlorophyll fluorescence to identify chemical and environmental stress in leaf tissue of three oak (Quercus) species. J. Arboric., v. 31, n. 5, p. 215-227, 2005.

PERCIVAL, G. C. Evaluation of physiological tests as predictors of young tree establishment and growth. J. Arboric., v. 30, n. 2, p. 80-92, 2004.

ROKICH, D. P.; DIXON, K. W. Recent advances in restoration ecology, with a focus on the Banksia woodland and the smoke germination tool. Austr. Bot., v. 55, n. 3, p. 375-389, 2007.

VARSHNEY, S. et al. Effects of herbicide applications in wheat fields. Is phytohormones application a remedy? Plant Sign. Behav., v. 7, n. 5, p. 570-575, 2012.

XIAOWEN, L. et al. Influence of two herbicides on photosynthesis of Eupatorium trapezoideum. J. AgroEnviron. Sci., v. 29, n. 7, p. 1247-1253, 2010.

YAMASHITA, O. M. et al. Resposta de varjão (Parkia multijuga) a subdoses de glyphosate.

Planta Daninha, v. 24, n. 3, p. 527-531, 2006. 